\title{
Effect of Substrate Temperature on Mn doped CdO thin films Prepared by Perfume Atomizer Spray Pyrolysis Method
}

\author{
M.Rajini $^{1}$, M.Karunakaran ${ }^{2}$, K.Kasirajan ${ }^{3}$, V.Annalakshmi ${ }^{4}$, S.Rajasekar ${ }^{5}$ \\ ${ }^{1,2,3}$ PG \& Research Department of Physics, Alagappa Government Arts College, Karaikudi, India- 630003 \\ ${ }^{4}$ Department of Physics, Pandian Sarswathi Yadav Engineering College, Arasanoor, India - 630581 \\ ${ }^{5}$ Department of Physics, Syed Ammal Engineering College, Ramanathapuram, India - 623502
}

Corresponding Author: tvdkaruna@gmail.com, Tel.: +91-8122841591

Available online at: www.isroset.org

Received: 18/Apr/2019, Accepted: 14/May/2019, Online: 30/Jun/2019

\begin{abstract}
Mn doped CdO thin films were deposited by perfume atomizer spray pyrolysis method on glass substrate by varying substrate temperature $\left(\mathrm{T}=200^{\circ} \mathrm{C}, 225^{\circ} \mathrm{C}, 250^{\circ} \mathrm{C}, 275^{\circ} \mathrm{C}, 300^{\circ} \mathrm{C}\right.$ ). The $\mathrm{X}$ - ray diffraction (XRD) analysis show that the prepared cadmium oxide thin films belongs to cubic structure with preferential orientation along with (111) direction. The thicknesses of the films were determined by Stylus profiler. The average optical transmittance of the $\mathrm{CdO}$ films in the range of $300-800 \mathrm{~nm}$, is about $58 \%$. Estimated band gap energy $\left(\mathrm{E}_{\mathrm{g}}\right)$ is $2.65 \mathrm{eV}$ and $2.5 \mathrm{eV}$. Photoluminescence (PL) spectra showed a strong emission peak around $523 \mathrm{~nm}$. A systematic study on the influence of the substrate temperatures on the optical, electrical and structural properties of $\mathrm{Mn}$ doped $\mathrm{CdO}$ thin films deposited by perfume atomizer spray have been reported.
\end{abstract}

Keywords—Thin films, X-ray Diffraction,thickness, transmittance, photoluminescence.

\section{INTRODUCTION}

Cadmium oxide $(\mathrm{CdO})$ is one of the promising transparent conducting oxides (TCOS) from II to VI groups of semiconductors which has a great potential use for optoelectronic devices [1]. CdO has a high optical transmittance in the visible and NIR region [2]. $\mathrm{CdO}$ is a $\mathrm{n}$ type semiconductor, has several attractive properties, high density, low resistivity, high melting point $[3,4]$. It was used in many industrial productions like solar cells, flat panel display optical communications, smart windows, photo transistors, Infrared detectors, ceramic glasses, storage batteries and other optoelectronic applications [5-11]. Doping suitable elements in metal oxide semiconductors show a critical role in tuning their optical and electrical properties of the potential application. The optical properties and bandgap can be modified by doping $\mathrm{CdO}$ with transition metals such as Aluminium, Fluorine, Tin, Copper, Zinc, Gadolinium, Boron and Indium [12-19]. These results infer that the optical and electrical properties of $\mathrm{CdO}$ can be enhanced by doping with suitable transition elements. In the present work, the effect substrate temperature on Mn doped $\mathrm{CdO}$ thin film on the structural, surface, optical and electrical properties of $\mathrm{CdO}$ thin films prepared by the perfume atomizer spray pyrolysis technique were reported.

\section{MATERIALS AND METHODS}

$\mathrm{Mn}$ doped $\mathrm{CdO}$ thin films were deposited on the glass substrates using the perfume atomizer spray pyrolysis technique. In the preparation of $\mathrm{CdO}$ films, $0.1 \mathrm{M}$ cadmium acetate $\left[\mathrm{Cd}\left(\mathrm{CH}_{3}(\mathrm{COO})_{2}\right)\right]$ was used as a source material of $\mathrm{Cd}$ and double distilled water was used as the solvent. $\mathrm{Mn}$ doping was achieved by mixing aqueous solution of manganese acetate with the above precursor solution. Microscopic glass slides were used as substrates. The resultant precursor solution was sprayed on preheated substrates at different temperature such as 200, 225, 250, 275 and $300^{\circ} \mathrm{C}$. The substrate temperature was controlled through a thermocouple with the help of PID temperature controller. The optimized deposition parameters such as substrate-spray nozzle distance $(25 \mathrm{~cm})$, spray angle (about $\left.45^{\circ}\right)$, spray time (3s) and spray interval (30s) were kept constant. After deposition, the coated substrates were allowed to cool down to room temperature. The thickness of the films was measured using Stylus Profilometer (SJ-301, Mitutoyo). The $\mathrm{X}$-ray diffraction (XRD) pattern of the prepared films were recorded using a Philips $\mathrm{X}$ Pert PRO X-ray diffraction system $(\mathrm{Cu} \mathrm{K} \alpha$ radiation, $\mathrm{K}=1.54056 \AA)$. The Surface morphology of the prepared samples was analyzed using scanning electron microscope. Optical transmittance spectrum was recorded in the wavelength range of 190-900 $\mathrm{nm}$ using UV-vis spectrometer (Shimadzu UV-1601). Room 
temperature Photoluminescence spectrum was recorded using (SHIMADZU-5301) spectrofluorometer.

\section{RESULTS AND DISCUSSION}

\section{X-Ray Diffraction Studies}

Thickness of the prepared $\mathrm{Mn}$ doped $\mathrm{CdO}$ thin films are measured by using the stylus profiler method. Film thickness increases with substrate temperature. The lattice constant of $\mathrm{CdO}$ thin films are calculated using the following formula,

$$
\frac{1}{d^{2}}=\frac{h^{2}+k^{2}+l^{2}}{a^{2}}
$$

The calculated film thickness, lattice constant 'a' and dspacing values are presented in table 1.

Figure 1 shows the X-ray diffraction pattern of Mn doped $\mathrm{CdO}$ thin films deposited by perfume atomizer spray pyrolysis method as a function of various substrate temperatures. The XRD pattern of reveals that all films are polycrystalline in nature and exhibits the cubic crystal structure as compared with JCPDS file no. 75-0591. The calculated lattice constant values agree with the standard JCPDS value. The Mn doping in the CdO film the intensity of the (200) plane is slightly decreased and the intensity of (111) peak is increased with temperature. The reason for the change in growth orientation is substitution of Mn ions into the Cd lattice sites. The results were well matched with F, $\mathrm{Mo}$ and $\mathrm{Mn}$ doped $\mathrm{CdO}$ thin films prepared by the spray pyrolysis method [20-23].

The slight increase of lattice constant is due to the increase in inter atomic spacing which results of substitution of smaller $\mathrm{Mn}^{2+}$ ions $(0.83 \AA)$ into larger $\mathrm{Cd}^{2+}$ ions $(0.95 \AA)$ $[24,25]$. To further increase of substrate temperature $\mathrm{Mn}$ doping concentration, the diffraction angle slightly shifted towards the lower angle owing to mixed phases such as $\mathrm{CdO}$ and $\mathrm{MnO}$ structures. This new diffraction plane is corresponding to the $\mathrm{MnO}$ (matched with JCPDS75-1090), which may be due to incorporation of $\mathrm{Mn}^{2+}$ ions. The average crystallite size (D) of the $\mathrm{CdO}$ film was calculated from the following Scherrer's equation for the (111) plane [26].

$$
\mathrm{D}=\frac{k \lambda}{\beta \operatorname{Cos} \theta}
$$

Where, $\mathrm{k}$ is a constant taken to be $0.94, \lambda$ is the X-ray wavelength, $\beta$ is the full-width at half-maximum of the peak and $\theta$ is the reflection angle

Dislocation density $(\delta)$ and strain $(\varepsilon)$ for (111) plane was evaluated using the relations $[28,29]$

$$
\delta=\frac{1}{D^{2}}
$$

$$
\varepsilon=\frac{\beta \operatorname{Cos} \theta}{4}
$$

The number of crystallites calculated using the formula

$$
\mathrm{N}=\frac{t}{D^{3}}
$$

The lattice distortion (L.D) developed in thin films can be evaluated from the relation [26]

$$
\text { L.D }=\frac{\beta}{4 \tan \theta}
$$

The calculated crystallite size, dislocation density, strain, Number of crystalline and lattice distortion values are presented in Table -2 .

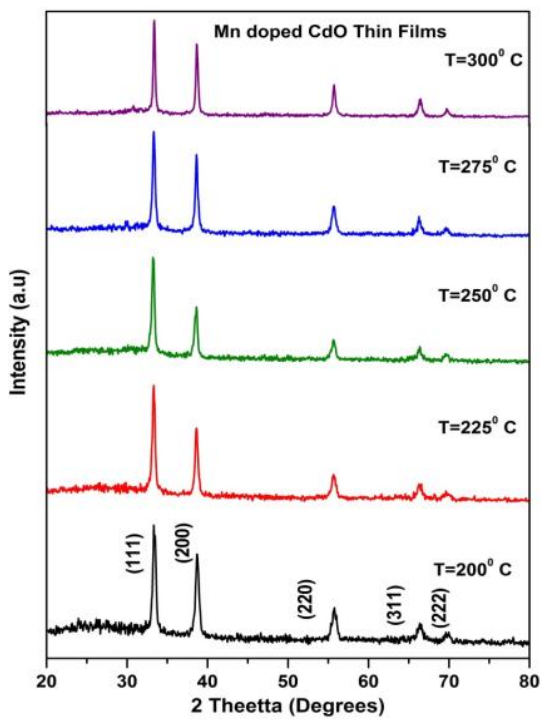

Figure 1: XRD pattern of Mn doped CdO thin films

Table 1: Micro-structural Parameter of Mn doped CdO thin films

\begin{tabular}{|c|c|c|c|}
\hline $\begin{array}{c}\text { Substrate } \\
\text { Temperature } \\
(\mathbf{T s})^{\mathbf{0}} \mathbf{C}\end{array}$ & $\begin{array}{c}\text { Thickness } \\
(\mathbf{t}) \boldsymbol{\mu \mathbf { m }}\end{array}$ & $\begin{array}{c}\mathbf{d} \text { lattice } \\
\mathbf{s p a c i n g} \\
\mathbf{\times 1 \mathbf { 1 0 } ^ { - 1 0 } \mathbf { m }}\end{array}$ & $\begin{array}{c}\text { Lattice } \\
\mathbf{c o n s t a n t} \\
\mathbf{\times 1 \mathbf { 1 0 } ^ { - 1 0 } \mathbf { m }} \mathbf{~}\end{array}$ \\
\hline 200 & 0.52 & 2.6704 & 4.629 \\
\hline 225 & 0.63 & 2.6790 & 4.643 \\
\hline 250 & 0.68 & 2.68607 & 4.657 \\
\hline 275 & 0.77 & 2.68672 & 4.656 \\
\hline 300 & 0.79 & 2.69012 & 4.663 \\
\hline
\end{tabular}

Table 2: Micro-structural parameters of Mn doped CdO thin films

\begin{tabular}{|c|c|c|c|c|c|}
\hline $\begin{array}{c}\text { Substrate } \\
\text { Temperature } \\
(\mathbf{T s})^{\mathbf{0}} \mathbf{C}\end{array}$ & $\begin{array}{c}\text { Crystallite } \\
\text { size (nm) }\end{array}$ & $\begin{array}{c}\text { Dislocation } \\
\mathbf{d e n s i t y} \\
\mathbf{\times 1 0}^{\mathbf{1 4}}\end{array}$ & $\begin{array}{c}\text { Strain } \\
\times \mathbf{1 0}^{\mathbf{3}}\end{array}$ & $\begin{array}{c}\text { No. } \\
\text { crystalline }_{\mathbf{1 0}}^{\mathbf{- 1 5}}\end{array}$ & $\begin{array}{c}\text { Lattice } \\
\text { Distortion } \\
\times \mathbf{1 0}^{\mathbf{3}}\end{array}$ \\
\hline 200 & 21.07 & 0.225 & 1.644 & 0.555 & 5.700 \\
\hline 225 & 24.07 & 0.172 & 1.440 & 0.451 & 5.021 \\
\hline 250 & 28.08 & 0.126 & 1.234 & 0.306 & 4.309 \\
\hline 275 & 33.70 & 8.800 & 1.028 & 0.201 & 3.585 \\
\hline 300 & 42.14 & 5.629 & 0.822 & 0.105 & 2.860 \\
\hline
\end{tabular}


Table 1 show that the $\mathrm{d}$ spacing and lattice constant slightly increases with substrate temperature. Table 2 shows the microstructural parameter of $\mathrm{Mn}$ doped $\mathrm{CdO}$ thin film at different temperature. As can be seen, the crystalline size of the $\mathrm{Mn}$ doped $\mathrm{CdO}$ films increases, but the strain and number of crystalline decreases with increasing temperature. The lattice constant and thickness slightly increases with temperature. However, it is observed that the crystalline size in the doped film does not vary in the XRD pattern, which is attributed to the lattice disorder produced in the films at $\mathrm{Mn}$ doping due to differences in the ionic radii of $\mathrm{Cd}^{2+}$ and $\mathrm{Mn}^{2+}$ ions.

\section{Surface Morphological Studies}

Figure 2. Shows the surface morphology of $\mathrm{Mn}$ doped $\mathrm{CdO}$ thin films at substrate temperature 200 and $275^{\circ} \mathrm{C}$. The grains formed on the surface are irregular in spherical shape and densely packed. The size of the grains is increased and uniformly distributed on the overall surface and the surface contains cauliflower like structures. The SEM images show that the surface is fully covered with grains of nearly uniform size and is free from pin holes. Thus it shows that the temperature of the substrate effectively modifies the surface morphology of the $\mathrm{Mn}$ doped $\mathrm{CdO}$ films. The composition of Mn doped CdO films was confirmed by energy dispersive Xray spectroscopy (EDAX).The EDAX spectra of the Mn doped $\mathrm{CdO}$ thin film shown in Fig. 3. The elements $\mathrm{Cd}, \mathrm{Mn}$, and $\mathrm{O}$ are present in the film and the other element $\mathrm{Si}$ which is not expected in the film may be resulted from the glass substrate.

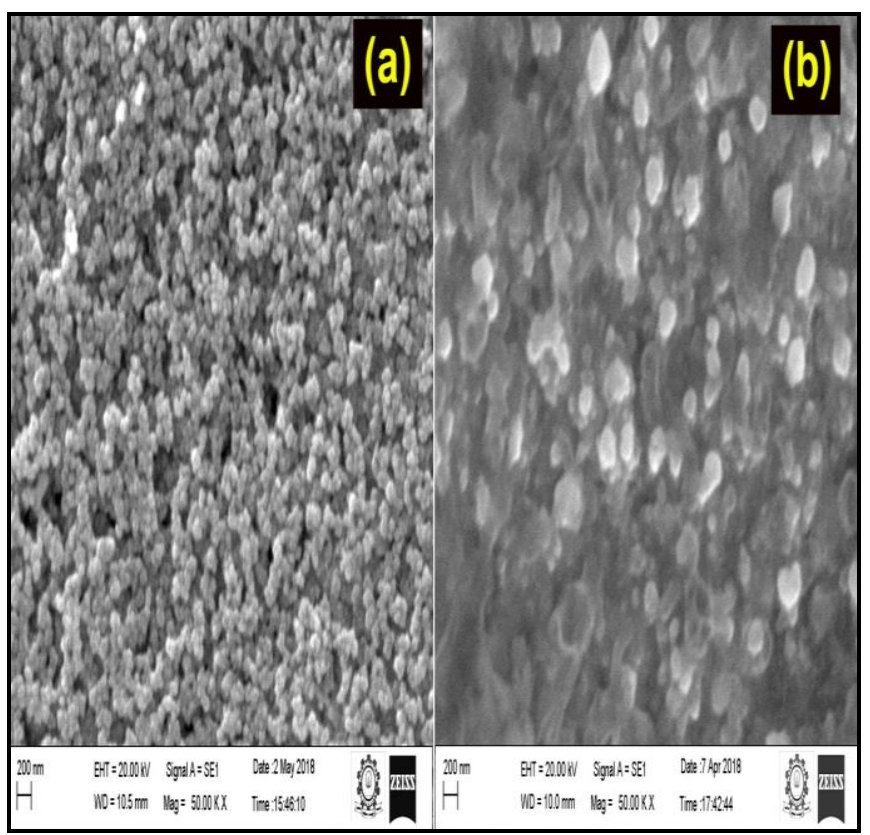

Figure 2: SEM image of Mn doped CdO thin films of substrate temperature (a) $200^{\circ} \mathrm{C}$ and (b) $275^{\circ} \mathrm{C}$

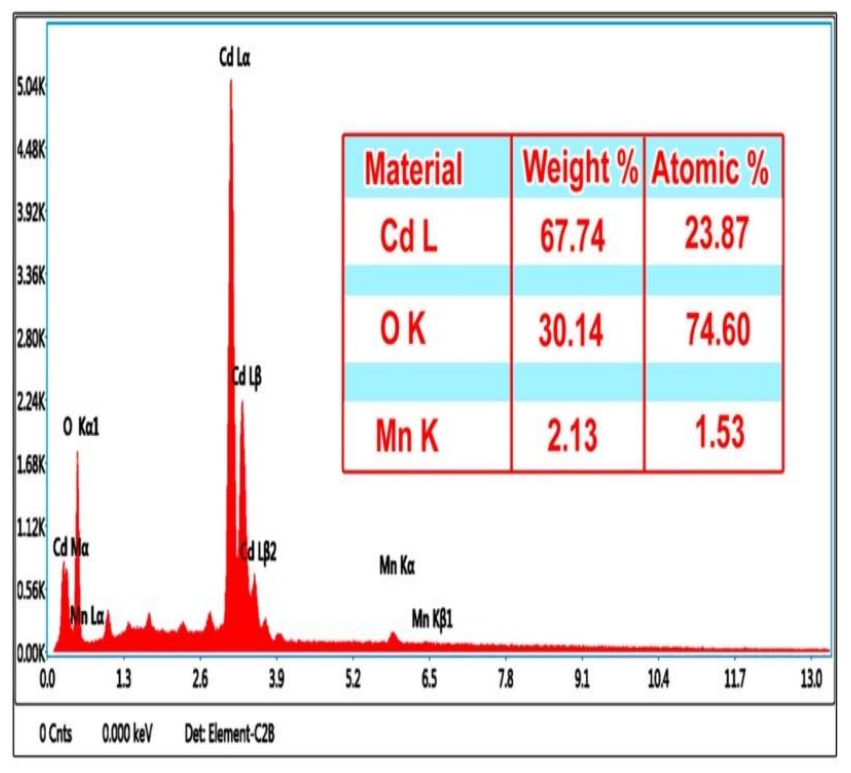

Figure 3: EDAX image of Mn doped $\mathrm{CdO}$ thin films

\section{Optical Studies}

The optical transmittance spectra of the Mn doped $\mathrm{CdO}$ films were recorded in the range of $400-800 \mathrm{~nm}$ at different temperature is shown in Fig. 4. The slight variation in transmittance was observed in the Mn doped films at different temperature. It may be due to the incorporation of more $\mathrm{Mn}$ in the lattice and interstitial positions and also a small increase in the free charge carrier concentration [3032]. Moreover, obtained results from optical transmission patterns revealed that with the increasing substrate temperature, optical transmittance decreases.

The direct bandgap determination is based on the extrapolated linear regression of the curve resulting from a plot of photon energy hv vs $(\alpha h v)^{2}$. The absorption coefficient $(\alpha)$ can be calculated from the transmittance spectrum. The optical band gap (Eg) of the films was estimated from the transmittance data where the photon energy (hv) and absorption coefficient $(\alpha)$ are related by the following equation [33].

$$
\alpha h v=B(h v-E g)^{r}
$$

For allowed direct transition, the value of $r=1 / 2$ and $B$ is constant. The above equation can be rearranged as

$$
\operatorname{In}(\alpha h v)=\operatorname{In} A+\operatorname{rIn}(h v-E g) \text {-------(7) }
$$

Figure 5 shows the Tauc's plot of Mn doped $\mathrm{CdO}$ film at different temperature. As clearly seen in Figure 5, the optical gap energy, decreased with increasing of substrate temperature from 2.65 to $2.5 \mathrm{eV}$, the band gap is narrowing due to the decrease in the transition tail width and shift effect $[34,35]$. 


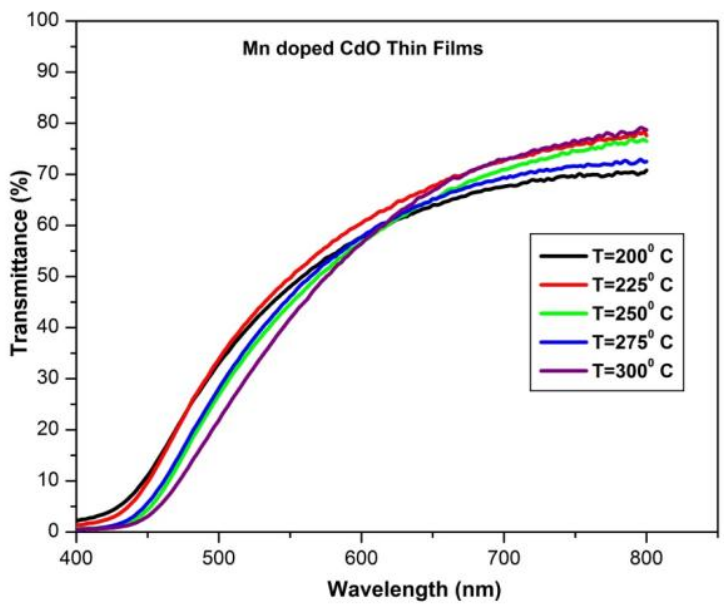

Figure 4: Transmittance spectra of Mn doped CdO thin films at different substrate Temperature

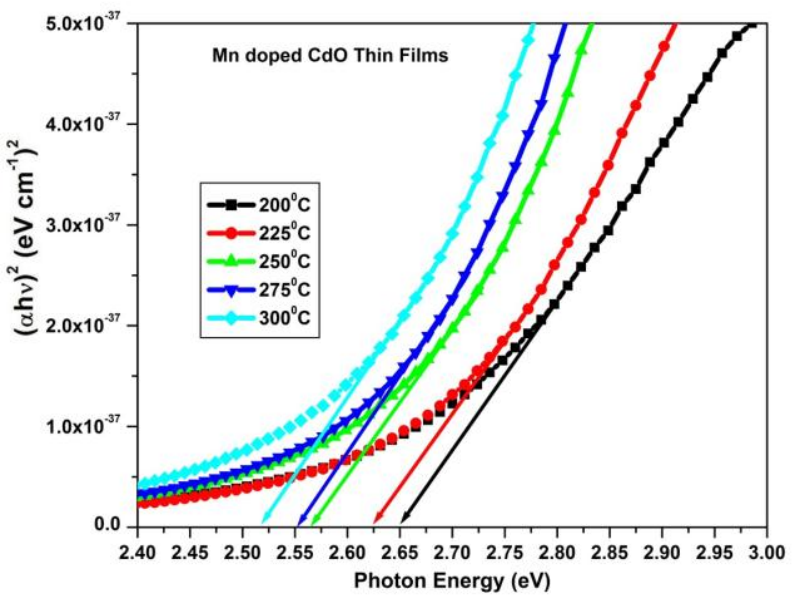

Figure 5: Tauc's plot of Mn doped $\mathrm{CdO}$ thin films at different substrate Temperature

\section{Photoluminescence spectra}

Photoluminescence (PL) is an important tool to investigate the quality of a thin film which depends on the size of the crystallites, morphology and chemical environment [36]. The PL spectra of $\mathrm{Mn}$ doped $\mathrm{CdO}$ at different substrate temperature is shown in figure 6. It was observed that the PL spectra consist of emission peaks centered at $494.76 \mathrm{~nm}$, $520.61 \mathrm{~nm}$ and $594.28 \mathrm{~nm}$ for $\mathrm{Mn}$ doped $\mathrm{CdO}$ at all substrate temperatures. This confirms the perfect stoichiometries nature of the doped samples at different substrate temperature. The peak centered at $494.76 \mathrm{~nm}$ may be attributed to the combination of the electrons from the conduction band and holes from the valence band. The peak at $520 \mathrm{~nm}$ is attributed to the excitonic transition which is size-dependent. The peakat594.28 $\mathrm{nm}$ may be ascribed to the deep trap emission and surface state emission that is less size-dependent. This peak confirms the quantum confinement effect of the as deposited samples which is ascribed to the near-band-edge (NBE) emission of CdO. This
NBE emission attributed to oxygen vacancies and cadmium interstitial [37, 38].

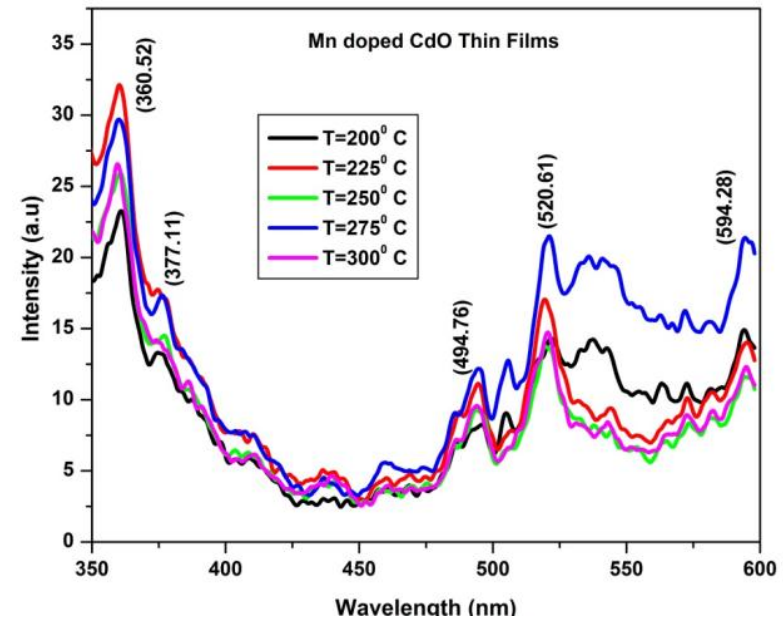

Figure 6: Photoluminescence spectra of Mn doped CdO thin films at different substrate Temperature

\section{CONCLUSION}

The transparent and conducting $\mathrm{Mn}$ doped $\mathrm{CdO}$ thin films were grown on glass substrate at different substrate temperature using perfumer atomizer spray pyrolysis method. The effects substrate temperature on structural, morphological and optical properties of $\mathrm{Mn}$ doped $\mathrm{CdO}$ films were investigated. The prepared films show the cubic crystal structure of the $\mathrm{CdO}$ with a slight variation of lattice parameter due to the replacement of cadmium by manganese atoms. The substrate temperature can be effectively modified on the structure and surface morphology of Mn doped $\mathrm{CdO}$ films. The optical band gap is slightly influenced by the substrate temperature and decreases from 2.65 to $2.5 \mathrm{eV}$ with temperature. SEM images show the evidence of morphological variation. EDAX spectrum shows the presence of $\mathrm{Cd}, \mathrm{O}$ and $\mathrm{Mn}$ ions in the prepared films.

\section{REFERENCES}

[1] Gulino, Antonino, and Giovanni Tabbì. "CdO thin films: a study of their electronic structure by electron spin resonance spectroscopy." Applied surface science Vol.245, Issue. 1-4, pp 322-327, 2005.

[2] Ristić, Mira, Stanko Popović, and Svetozar Musić. "Formation and properties of $\mathrm{Cd}(\mathrm{OH}) 2$ and $\mathrm{CdO}$ particles." Materials letters Vol.245, Issue. 1-4, pp 322-327, 2004.

[3] Benko, F. A., and F. P. Koffyberg. "Quantum efficiency and optical transitions of $\mathrm{CdO}$ photoanodes." Solid state communications Vol.57, Issue. 12, pp 901-903, 1986.

[4] Choi, Y-S., C-G. Lee, and S. M. Cho. "Transparent conducting ZnxCd1- $x O$ thin films prepared by the sol-gel process." Thin Solid Films Vol.289, Issue. 1-2, pp 153-158, 1996.

[5] Al-Anssari, Ramiz A., Nadir F. Habubi, and Jinan Ali Abd. "Fabrication and characterization of $n-\mathrm{CdO}: \mathrm{In} / \mathrm{p}$-Si thin film solar cell." Journal of Electron Devices Vol.17, pp 1457-1464, 2013. 
[6] Sankarasubramanian, K., P. Soundarrajan, K. Sethuraman, and K. Ramamurthi. "Chemical spray pyrolysis deposition of transparent and conducting $\mathrm{Fe}$ doped $\mathrm{CdO}$ thin films for ethanol sensor." Materials Science in Semiconductor Processing Vol.40, pp 879-884, 2015.

[7] Bari, R. H., S. B. Patil, and S. B. Deshmukh. "Journal of Nanoscience and Technology." Journal of Nanoscience and Technology Vol.2, Issue. 3, pp 181-185, 2016.

[8] Bulakhe, R. N., and C. D. Lokhande. "Chemically deposited cubic structured $\mathrm{CdO}$ thin films: use in liquefied petroleum gas sensor." Sensors and Actuators B: Chemical, Vol.200, pp 245-250, 2014.

[9] Millesi, Salvatrice, Matteo Schilirò, Francesco Greco, Isodiana Crupi, Giuliana Impellizzeri, Francesco Priolo, Russell G. Egdell, and Antonino Gulino. "Nanostructured CdO thin films for water treatments." Materials Science in Semiconductor Processing, Vol.42, pp 85-88, 2026.

[10] Usharani, K., N. Raja, N. Manjula, V. S. Nagarethinam, and A. R. Balu. "Characteristic Analysis on the Suitability of $\mathrm{CdO}$ Thin Films Towards Optical Device Applications-Substrate Temperature Effect." International Journal of Thin Films Science and Technology, Vol.4, Issue. 2, pp 89, 2015.

[11] Cheemadan, Saheer, Amiruddin Rafiudeen, and Maniyeri Chandroth Santhosh Kumar. "Highly transparent conducting CdO thin films by radiofrequency magnetron sputtering for optoelectronic applications." Journal of Nanophotonics, Vol.10, Issue. 3, pp 033007, 2016.

[12] Saha, B., S. Das, and K. K. Chattopadhyay. "Electrical and optical properties of Al doped cadmium oxide thin films deposited by radio frequency magnetron sputtering." Solar energy materials and solar cells, Vol.91, Issue. 18, pp 1692-1697, 2007.

[13] Deokate, R. J., S. M. Pawar, A. V. Moholkar, V. S. Sawant, C. A. Pawar, C. H. Bhosale, and K. Y. Rajpure. "Spray deposition of highly transparent fluorine doped cadmium oxide thin films." Applied surface science, Vol.254, Issue. 7, pp 2187-2195, 2008.

[14] de León-Gutiérrez, L. R., J. J. Cayente-Romero, J. M. Peza-Tapia, E. Barrera-Calva, J. C. Martínez-Flores, and M. Ortega-López. "Some physical properties of Sn-doped CdO thin films prepared by chemical bath deposition." Materials letters, Vol.60, Issue. 29-30, pp 3866-3870, 2006.

[15] Benhaliliba, M., C. E. Benouis, A. Tiburcio-Silver, F. Yakuphanoglu, A. Avila-Garcia, A. Tavira, R. R. Trujillo, and Z. Mouffak. "Luminescence and physical properties of copper doped $\mathrm{CdO}$ derived nanostructures." Journal of Luminescence, Vol.132, Issue. 10, pp 2553-2658, 2012.

[16] Usharani, K., and A. R. Balu. "Structural, optical, and electrical properties of $\mathrm{Zn}$-doped $\mathrm{CdO}$ thin films fabricated by a simplified spray pyrolysis technique." Acta Metallurgica Sinica (English Letters), Vol.28, Issue. 1, pp 64-71, 2015.

[17] Pan, L. L., G. Y. Li, and J. S. Lian. "Structural, optical and electrical properties of cerium and gadolinium doped $\mathrm{CdO}$ thin films." Applied Surface Science, Vol.274, pp 365-370, 2013.

[18] Yakuphanoglu, F. "Synthesis and electro-optic properties of nanosized-boron doped cadmium oxide thin films for solar cell applications." Solar Energy, Vol.85, Issue. 11, pp 2704-2709, 2011.

[19] Flores-Mendoza, M. A., R. Castanedo-Perez, G. Torres-Delgado, P. Rodriguez-Fragoso, J. G. Mendoza-Alvarez, and O. ZelayaAngel. "Photoluminescence in undoped (CdO) $1-x-(\operatorname{InO3/2)} x$ thin films at room temperature, $0 \leq x \leq 1$." Journal of Luminescence, Vol.135, pp 133-138, 2013.

[20] Farooq, W. A., L. R. Al-Otaibi, A. S. Al-Dwayyan, F. Yakuphanoglu, and M. Atif. "Effect of Laser Exposure on Structural and Optical Properties of $\mathrm{CdO}$ and Li Doped CdO
Nano Structured Thin Film Synthesized by Sol Gel Method." Journal of Nanoelectronics and Optoelectronics, Vol.11, Issue. 4, pp 536-542, 2016.

[21] Kumaravel, R., S. Bhuvaneswari, K. Ramamurthi, and V. Krishnakumar. "Structural, optical and electrical properties of molybdenum-doped cadmium oxide thin films prepared by spray pyrolysis method." Applied Physics A, Vol.109, Issue. 3, pp 579. 584, 2012.

[22] Deokate, R. J., S. M. Pawar, A. V. Moholkar, V. S. Sawant, C. A. Pawar, C. H. Bhosale, and K. Y. Rajpure. "Spray deposition of highly transparent fluorine doped cadmium oxide thin films." Applied surface science, Vol.254, Issue. 7, pp 2187-2195, 2008.

[23] Bilgin, V., I. Akyuz, S. Kose, and F. Atay. "Characterization of Mn-incorporated $\mathrm{CdO}$ films grown by ultrasonic spray pyrolysis." Semiconductor science and technology, Vol.21, Issue. 5, pp 579, 2006.

[24] Ahmad, Tokeer, Sarvari Khatoon, Samuel E. Lofland, and Gohil S. Thakur. "Structural characterization and properties of nanosized $\mathrm{Cd} 1-x \mathrm{CoxO}$ dilute magnetic semiconductors prepared by solvothermal method." Materials Science in Semiconductor Processing, Vol.17, pp 207-215, 2014.

[25] Ahmad, Tokeer, Sarvari Khatoon, Kelsey Coolahan, and Samuel E. Lofland. "Solvothermal synthesis, optical and magnetic properties of nanocrystalline $C d 1-x M n x O(0.04<x=0.10)$ solid solutions." Journal of Alloys and Compounds, Vol.558, pp 117. 124, 2013.

[26] B.D. Cullity, Elements of X-ray diffraction, Addison-Wesley, Massachusetts, 1956.

[27] Radhi Devi K., Selvan G., Karunakaran M., Rajesh Kanna G., Kasirajan K and Annalakshmi V, IJRSR, Vol.9, Issue. 1, pp 2360623609, 2018.

[28] K.Radhi Devi, G. Selvan, M. Karunakaran, G. Rajesh, Kanna, S. Maheswari, Journal of Applied Chemical Science International, Vol.7, Issue. 1, pp 25-30, 2016.

[29] V.Annalakshmi, M.Karunakaran, C.Subbu, IJSART, Vol.4, Issue. 1, pp 382-386, 2018.

[30] de Biasi, Ronaldo Sergio, and Maria Lúcia Netto Grillo. "Measurement of small concentrations of manganese in cadmium oxide $(\mathrm{CdO})$ using electron magnetic resonance." Ceramics International, Vol.39, Issue. 2, pp 2171-2173, 2013.

[31] Eid, Kh M., H. O. Taha, M. A. Kamel, A. E. Ashour, and WS Abdel Halim. "DFT calculations of the CO adsorption on Mn, Fe, $\mathrm{Co}$, and $\mathrm{Au}$ deposited at $\mathrm{MgO}\left(\begin{array}{lll}1 & 0 & 0\end{array}\right)$ and $\mathrm{CdO}\left(\begin{array}{lll}1 & 0 & 0\end{array}\right) . "$ Applied Surface Science, Vol.258, Issue. 24, pp 9876-9890, 2012.

[32] Dong, Wenting, and Congshan Zhu. "Optical properties of surface-modified CdO nanoparticles." Optical Materials, Vol.22, Issue. 3, pp 227-233, 2003.

[33] Rajashree, C., A. R. Balu, and V. S. Nagarethinam. "Substrate temperature effect on the Physical properties of Spray deposited Lead sulfide thin films suitable for solar control coatings." Int. J. Chem. Tech. Res, Vol.6, pp 347-360, 2014.

[34] Benramache, Said, Foued Chabane, Boubaker Benhaoua, and Fatima Z. Lemmadi. "Influence of growth time on crystalline structure, conductivity and optical properties of $\mathrm{ZnO}$ thin films." Journal of Semiconductors, Vol.34, Issue. 2, pp 023001, 2013.

[35] Benhaoua, Boubaker, Achour Rahal, and Said Benramache. "The structural, optical and electrical properties of nanocrystalline ZnO: Al thin films." Superlattices and Microstructures, Vol.68, pp 38-47, 2014.

[36] Dong, Wenting, and Congshan Zhu. "Optical properties of surface-modified CdO nanoparticles." Optical Materials, Vol.22, Issue. 3, pp 227-233, 2003. 
[37] Kuo, Tz-Jun, and Michael H. Huang. "Gold-catalyzed lowtemperature growth of cadmium oxide nanowires by vapor transport." The Journal of Physical Chemistry B, Vol.110, Issue. 28, pp 13717-13721, 2006.

[38] Acharya, A. D., Shweta Moghe, Richa Panda, S. B. Shrivastava, Mohan Gangrade, T. Shripathi, D. M. Phase, and V. Ganesan. "Effect of Cd dopant on electrical and optical properties of $\mathrm{ZnO}$ thin films prepared by spray pyrolysis route." Thin Solid Films, Vol.525, pp 49-55, 2012.

\section{AUTHORS PROFILE}

Dr. M.Karunakaran is currently working as an Assistant Professor in Department of Physics, Alagappa Government Arts College, Karaikudi. He has published more than 50 research papers in reputed international journals and it's also available online. His main research work focuses on Materials Science (Thin films and

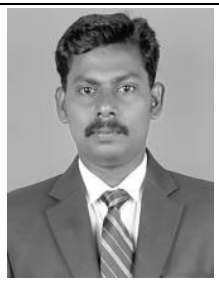
Nano materials synthesis) He has 13 years of teaching experience and 10 years of research experience.

Mr. M.Rajini is working as a school teacher in Tamilnadu Government. Currently he doing $\mathrm{Ph} . \mathrm{D}$ in Alagappa Government Arts College, Karaikudi. He has 10 years of teaching experience and 3 years of Research Experience. His area of research is Synthesis and Characterization of Transparent Conductiong Oxide thin films, Nanoparticles and crystals etc. He has published more than five papers in international Journals.

Mr. K.Kasirajan perused M. Phil., (Physics) in 2015 from Alagappa Government Arts College, Karaikudi, (TN), India. Currently, he is doing Ph.D. from Alagappa University, Karaikudi, (TN), India. His area of research is Synthesis and Characterization of Dilute magnetic Semiconducting thin films, Nanoparticles and Green Synthesis etc. He has published more than 20 papers in International Journals.

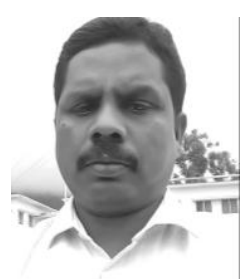

Miss. V.Annalakshmi perused M. Phil., (Physics) in 2018 from Alagappa Government Arts College, Karaikudi, (TN), India. Currently, she is working as an Assistant professor in Pandian Sarswathi Yadav Engineering College, Arsanoor, Madurai, (TN), India. Her area of research is Synthesis and Characterization of Dilute magnetic Semiconducting thin films, Nanoparticles and Green Synthesis etc. He has published more than 10 papers in International Journals.

Mr. S. Rajasekar completed compleated M.Sc., M. Phil., Ph.D., (Physics). Currently, he working as an Associate professor in Syed Ammal Engineering College, Ramanathapuram (TN), India. His area of research is Synthesis and Characterization of Crystals. He has published more than 20 papers in International Journals. He has 15 years of teaching experience and 10 years of research experience. 